\title{
Lateral Variation in Crustal Structure of the Northern Tibetan Plateau Inferred from Teleseismic Receiver Functions
}

\author{
by Lupei Zhu, Thomas J. Owens, and George E. Randall
}

\begin{abstract}
We investigate lateral variations in crustal structure across the northern boundary of the Tibetan Plateau using the receiver functions at three broadband stations deployed during the 1991-1992 Tibet PASSCAL experiment. The first $5 \mathrm{sec}$ of the receiver functions vary systematically with backazimuth: the radial receiver functions are symmetric across the $\mathrm{N}-\mathrm{S}$ axis while the tangential receiver functions are antisymmetric across this axis. This symmetry can be modeled by E-W striking dipping interfaces in the upper-middle crust. The strike direction is consistent with the E-W trend of surface geology. Modeling a $P$-to- $S$ converted phase in the receiver functions at each station suggests that there is a mid-crustal low-velocity layer with its upper boundary dipping $20^{\circ}$ to $30^{\circ}$ to the south. In addition, a shallow northwarddipping interface is responsible for the "double-peaked" direct $P$ arrivals in the radial receiver functions and large tangential motions at one of the stations. The low-velocity layer, together with other geological and seismological observations, suggests that there is a hot, possibly partial melt zone in the middle crust of northern Tibet. Alternately, dipping velocity interfaces might be associated with some buried thrust faults in the upper crust that accommodated crust shortening during the plateau formation.
\end{abstract}

\section{Introduction}

The Tibetan Plateau, bounded by the Kunlun mountains in the north and Himalayas in the south, with an average elevation of $5 \mathrm{~km}$ and an areal extent of nearly $7 \times 10^{5} \mathrm{~km}^{2}$, has long been an interesting and challenging subject in the geosciences. The uplift of Tibetan Plateau is the result of the collision of the Indian plate with Eurasia, which began during Middle Eocene, 45 m.y.a. However, the details of the uplift mechanism remain controversial. Among the most popular uplift models are the underthrust model and its variants (Argand, 1924; Zhao and Morgan, 1985; Beghoul et al., 1993), the crustal shortening and thickening model (Dewey and Bird, 1970; Dewey and Burke, 1973), and the lateral crustal extrusion model (Molnar and Tapponnier, 1977; Tapponnier et al., 1982). Due to insufficient information on the lithospheric structure of the plateau, it is difficult to discriminate among different uplift models.

Most geological and geophysical investigations on the plateau have been concentrated on the southern Tibet, near the Himalayas. Comparatively, the structure near the northern boundary of the plateau was poorly resolved. Recently, in a joint research project conducted by the Institute of Geophysics, State Seismological Bureau, China, the University of South Carolina, and the State University of New York at Binghamton, 11 broadband three-component seismic recorders were deployed on the plateau for 1 year (Fig. 1). Three stations, TUNL, BUDO, and ERDO, placed across the northern boundary of the plateau, provided an opportunity to study the crustal and upper-mantle structure of this area. We use teleseismic $P$ waveforms to study the lateral variations of the crustal structure. We show that there is strong lateral variation in the crust of the northern plateau and that most of this variation is caused by E-W striking dipping velocity interfaces in the upper-middle crust.

\section{Receiver Functions and Dipping Interfaces}

Teleseismic $P$ waveforms contain information about near-source and near-receiver structure. Using the method of Langston (1979), the source and distant path effects can be removed from $P$ waveforms by deconvolving the vertical from the horizontal components. The source-equalized teleseismic waveform is called the receiver function and is most sensitive to the $P$-to- $S$ conversions from structures beneath the recording site (Owens et al., 1984).

The radial receiver functions are often modeled by horizontally stratified velocity structure using a time-domain inversion technique (Owens et al., 1984; Ammon et al., 1990). This method has been applied to numerous areas and is efficient in estimating the velocity-depth variation of the crust. However, if the tangential receiver function is com- 


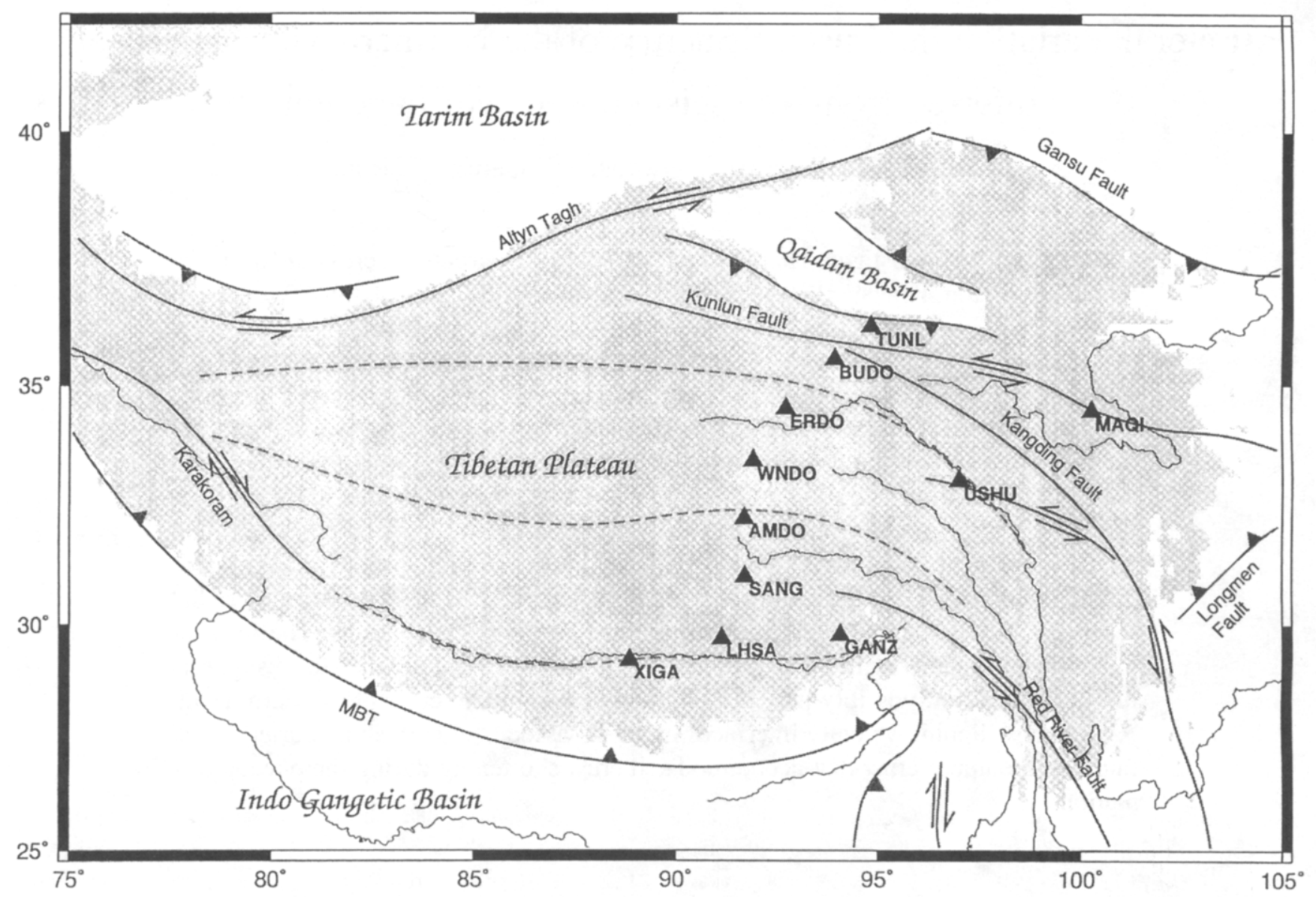

Figure 1. The Tibetan Plateau, major faults, and broadband stations of 1991-1992

PASSCAL experiment. Shading indicates elevation above $3 \mathrm{~km}$.

parable in amplitude to the radial receiver function, which indicates strong lateral heterogeneity beneath the site, modeling the details of the radial receiver function with horizontally stratified velocity will produce erroneous results.

One special case of lateral heterogeneity is a dipping planar velocity interface. In this case, both the radial and tangential receiver functions vary with backazimuth in a predictable pattern. In Figure 2, we show synthetic receiver functions for a model that contains a mid-crustal low-velocity layer with upper boundary dipping $20^{\circ}$ to the south. The interface is at depth of $20 \mathrm{~km}$, where the $S$ velocity is 3.5 $\mathrm{km} / \mathrm{sec}$ above and $3.0 \mathrm{~km} / \mathrm{sec}$ below. Synthetics are calculated using a 3D raytracing method of Langston (1977). The ray parameter is $0.068 \mathrm{sec} / \mathrm{km}$, which corresponds to an epicentral distance of $50^{\circ}$. The waveform variation with backazimuth is systematic: the radial receiver functions are symmetric across a line parallel to the dip direction of the interface, while the tangential receiver functions are antisymmetric about this direction (indicated by arrow in Fig. 2). The tangential receiver function is largest when the $P$ r wave approaches from the strike direction and is zero when the ray comes from a direction parallel to the dip direction. The $P$-to- $S$ converted wave generated at the dipping inter- face is indicated by a thick gray line in the figure. This negative-amplitude phase emerges for southern backazimuths, has a maximum amplitude from the dip direction, and vanishes gradually away from the dip direction.

Therefore, if a dipping interface is the major cause of lateral heterogeneity under a station, it is easy to determine the dip and strike directions by examining a backazimuthal profile of receiver functions. The dip angle, velocity contrast, and the depth of the interface can be estimated by modeling the amplitude and arrival time of the converted phase from the interface. A trade-off, however, exists between the dip angle and the velocity contrast across the interface (Owens and Crosson, 1988). In Figures 3a and 3b, we show the variation of radial and tangential amplitudes of the $P$-to$S$ converted phases with backazimuth at different dip angles. Figure $3 \mathrm{c}$ is the variation of maximum radial amplitude with velocity below the interface, after fixing the velocity above at $3.5 \mathrm{~km} / \mathrm{sec}$. The dip angle controls the shape of the amplitude variation with backazimuth and also affects the maximum radial amplitude, while the velocity difference across the interface contributes mainly to the maximum amplitude. However, to produce the same maximum amplitude with velocity contrast differing $0.1 \mathrm{~km} / \mathrm{sec}$, the dip angles will 


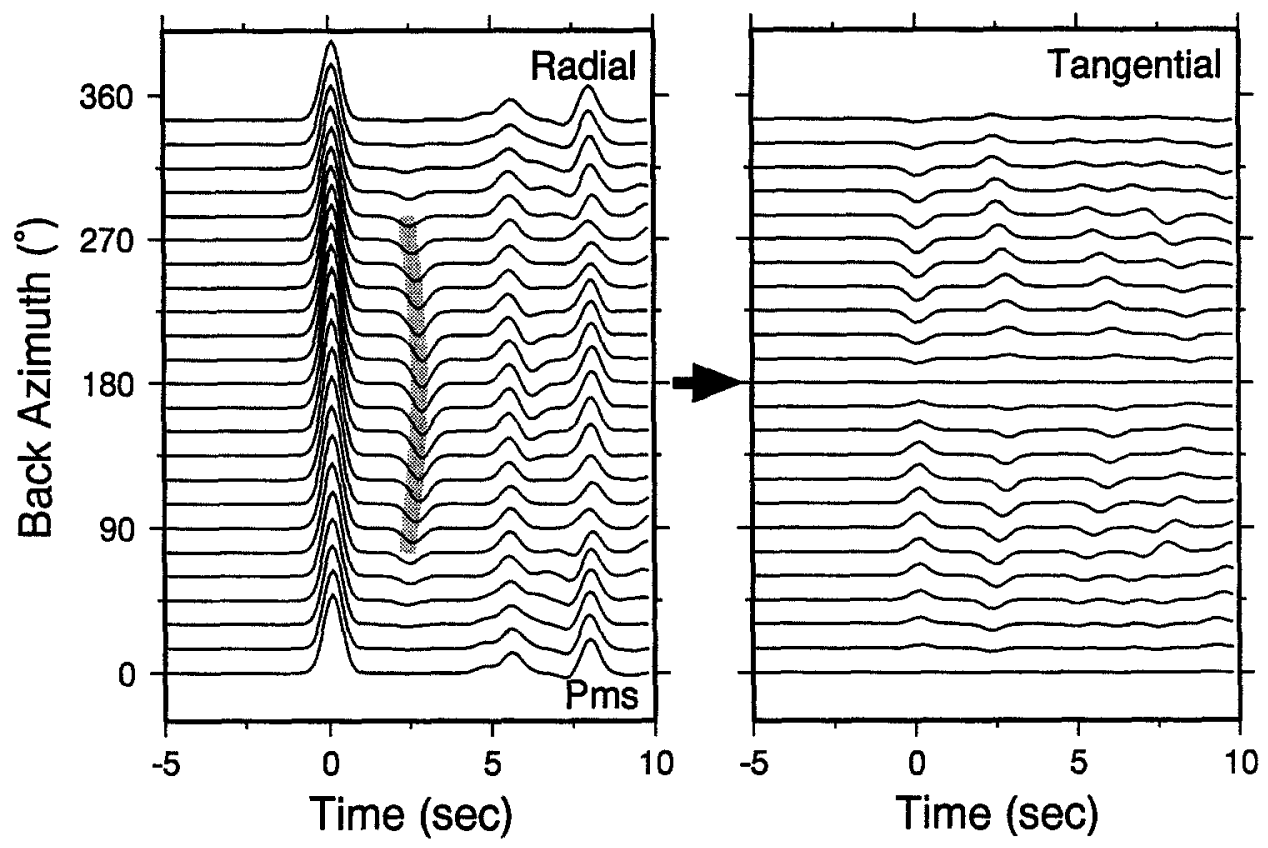

Figure 2. Synthetic receiver functions for a model containing a mid-crustal lowvelocity layer with its upper boundary dipping $20^{\circ}$ to the south. $P$-to- $S$ converted phase from the dipping interface is indicated by the thick gray line. $P m s$ is the $P$-to- $S$ converted wave from the Moho.

differ more than $10^{\circ}$ (Fig. 3c), which have observable shape differences in the amplitude variation with backazimuth (Figs. 3a and 3b). Thus, if the data have sufficient backazimuth coverage, reasonable constraints can be made on the dip angle and velocity contrast across the interface.

\section{Receiver Function Variation with Backazimuth}

More than 300 teleseismic events ranging between $35^{\circ}$ to $95^{\circ}$ in epicentral distance were recorded during the experiment. Instrumentation details about the experiment can be found in Owens et al. (1993). A preliminary study of the receiver functions at three sites (TUNL, WNDO, and XIGA) located in the northern, central, and southern plateau showed the great thickness of the crust ( 60 to $80 \mathrm{~km}$ ) and a difference in velocity structures between the north-central and southern Tibetan Plateau (Zhu et al., 1993). Large tangential motions were also observed at TUNL and XIGA.

Three stations, TUNL, BUDO, and ERDO, were located across the north boundary of the plateau, which is defined by an E-W striking left-lateral fault system, the Kunlun Fault System (Fig. 1). The elevation increases from $3 \mathrm{~km}$ in the Qaidam Basin in the north to more than $4.5 \mathrm{~km}$ on the plateau. During several recent geotraverses, some thrust faults were discovered in the northern Tibet, for example, the South Qaidam Border Thrust Fault and Fenghuoshan Thrust Faults (Kidd et al., 1988). The surface geology in this area includes highly deformed Permian subduction-related rocks and Upper Paleozoic plutons (Dewey et al., 1988).

Excellent backazimuthal coverage enables us to study the lateral variations of the crustal structure using the variation of the receiver function waveforms. The three-component teleseismic recordings were cut with a time window of $180-\mathrm{sec}$ long beginning $60 \mathrm{sec}$ before the direct $P$ arrival. The horizontal components were then rotated to radial and tangential directions and deconvolved with the vertical component in the frequency domain. A Gaussian parameter of 2.5 was used to exclude frequencies above $1 \mathrm{~Hz}$. To stabilize the deconvolutions, we used a range of water levels from 0.1 to 0.0001 . Details on the calculation of receiver function are described elsewhere (e.g., Langston, 1979; Owens et al., 1984).

For each station, the teleseismic events are divided into groups of backazimuth range less than $10^{\circ}$, according to the waveform similarity of the receiver functions. We found that differences in epicentral distance do not strongly affect the waveforms, so some of the groups span a distance range of more than $20^{\circ}$. The receiver functions in each group are then stacked. The backazimuthal/distant range and the number of events for each stacking suite are listed in Table 1.

Figures 4 through 6 show the backazimuthal profiles of the stacked receiver functions at the three stations. It is clear that there is strong lateral variation in the upper-middle crust of this region, as evidenced by the variation of radial receiver function waveforms and large tangential motions at all three stations. Also, the waveforms vary with backazimuth in the pattern predicted by dipping interfaces described above. Both the symmetry of radial receiver functions and the antisymmetry of tangential receiver functions across roughly $\mathrm{N}-\mathrm{S}$ direction are noticeable in the first $5 \mathrm{sec}$ of the wave- 


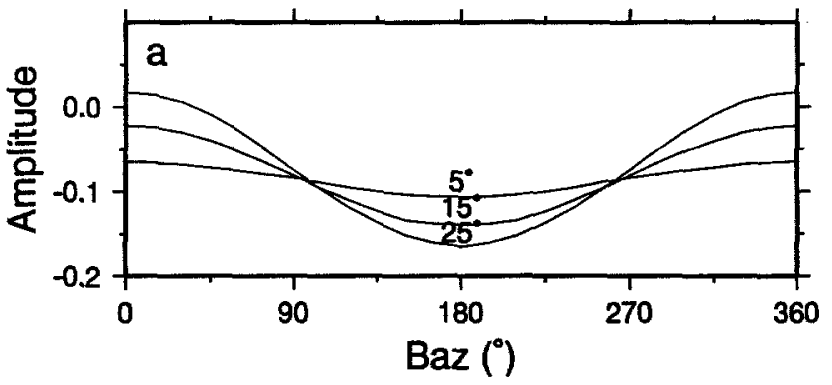

Table 1

Backazimuth/Distance Range and Number of Events of Stacking Suites
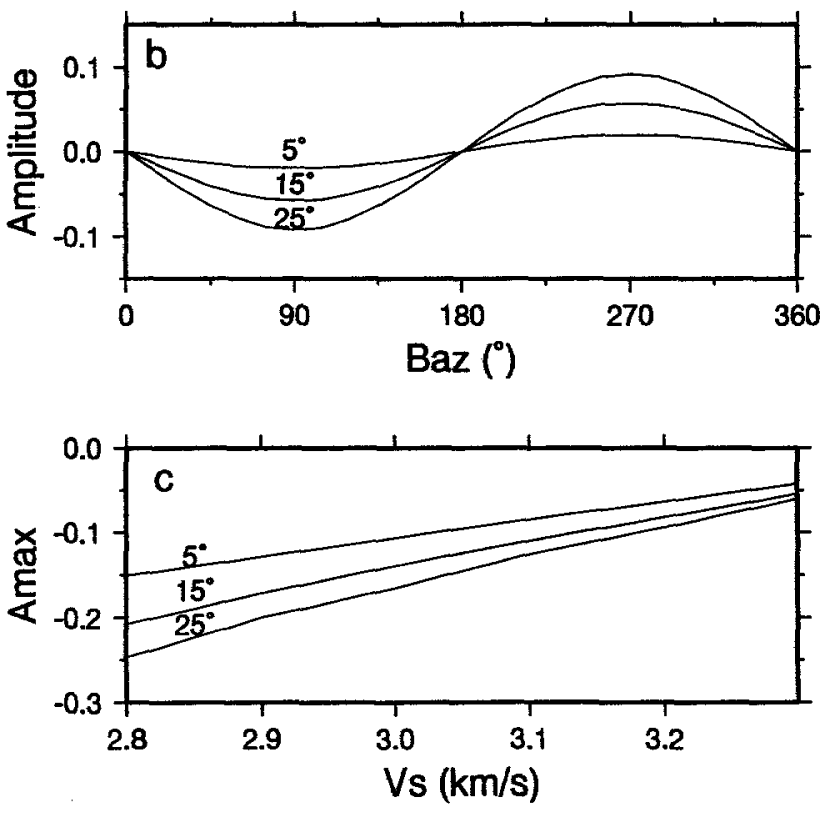

Figure 3. Variation of (a) radial and (b) tangential amplitude with backazimuth of the converted phase from the dipping interface at different dip angles. (c) Variation of maximum amplitude with velocity below the interface at different dip angles. The $S$ velocity above the interface is fixed at $3.5 \mathrm{~km} / \mathrm{sec}$.

\begin{tabular}{|c|c|c|c|c|}
\hline $\operatorname{Baz}\left({ }^{\circ}\right)$ & $\Delta \mathrm{Baz}\left(^{\circ}\right)$ & Distance $\left(^{\circ}\right)$ & ADistance ( $\left.{ }^{\circ}\right)$ & $N$ \\
\hline \multicolumn{5}{|c|}{ BUDO } \\
\hline 5 & 0 & 46 & 0 & 1 \\
\hline 27 & 2 & 92 & 10 & 5 \\
\hline 44 & 10 & 58 & 21 & 12 \\
\hline 59 & 12 & 42 & 9 & 34 \\
\hline 79 & 10 & 38 & 3 & 21 \\
\hline 89 & 4 & 42 & 5 & 7 \\
\hline 102 & 9 & 50 & 3 & 4 \\
\hline 130 & 15 & 47 & 22 & 34 \\
\hline 114 & 9 & 73 & 32 & 29 \\
\hline 145 & 5 & 50 & 4 & 2 \\
\hline 164 & 9 & 42 & 6 & 6 \\
\hline 181 & 0 & 51 & 0 & 2 \\
\hline 211 & 0 & 58 & 0 & 1 \\
\hline 243 & 0 & 40 & 0 & 1 \\
\hline 255 & 0 & 51 & 0 & 1 \\
\hline 267 & 1 & 32 & 1 & 2 \\
\hline 275 & 0 & 36 & 0 & 1 \\
\hline 289 & 6 & 42 & 18 & 6 \\
\hline 303 & 0 & 53 & 0 & 1 \\
\hline 346 & 0 & 55 & 0 & 1 \\
\hline Total & & & & 171 \\
\hline \multicolumn{5}{|c|}{ TUNL } \\
\hline 6 & 2 & 45 & 1 & 2 \\
\hline 29 & 10 & 89 & 27 & 8 \\
\hline 45 & 7 & 58 & 17 & 11 \\
\hline 59 & 7 & 42 & 8 & 33 \\
\hline 66 & 8 & 38 & 4 & 15 \\
\hline 80 & 8 & 37 & 4 & 25 \\
\hline 90 & 8 & 40 & 5 & 12 \\
\hline 102 & 10 & 49 & 3 & 6 \\
\hline 114 & 10 & 76 & 32 & 27 \\
\hline 128 & 9 & 45 & 22 & 24 \\
\hline 136 & 12 & 47 & 12 & 25 \\
\hline 152 & 8 & 48 & 2 & 4 \\
\hline 167 & 2 & 41 & 1 & 8 \\
\hline 182 & 0 & 52 & 0 & 2 \\
\hline 212 & 0 & 59 & 0 & 1 \\
\hline 243 & 0 & 41 & 0 & 1 \\
\hline 267 & 1 & 33 & 1 & 2 \\
\hline 255 & 0 & 60 & 14 & 2 \\
\hline 273 & 3 & 37 & 0 & 2 \\
\hline 285 & 1 & 38 & 4 & 2 \\
\hline 294 & 12 & 46 & 15 & 5 \\
\hline 346 & 0 & 54 & 0 & 1 \\
\hline Total & & & & 217 \\
\hline \multicolumn{5}{|c|}{ ERDO } \\
\hline 27 & 2 & 94 & 10 & 4 \\
\hline 43 & 10 & 61 & 20 & 11 \\
\hline 58 & 10 & 44 & 8 & 30 \\
\hline 70 & 6 & 39 & 1 & 5 \\
\hline 79 & 6 & 39 & 3 & 8 \\
\hline 89 & 9 & 44 & 9 & 5 \\
\hline 112 & 9 & 75 & 26 & 22 \\
\hline 128 & 12 & 47 & 21 & 31 \\
\hline 143 & 6 & 50 & 4 & 4 \\
\hline 161 & 0 & 42 & 0 & 1 \\
\hline 164 & 0 & 39 & 0 & 2 \\
\hline 179 & 0 & 50 & 0 & 2 \\
\hline 210 & 0 & 57 & 0 & 1 \\
\hline 272 & 6 & 33 & 3 & 2 \\
\hline 287 & 0 & 37 & 4 & 2 \\
\hline 292 & 2 & 45 & 11 & 3 \\
\hline 303 & 0 & 53 & 0 & 1 \\
\hline Total & & & & 132 \\
\hline
\end{tabular}



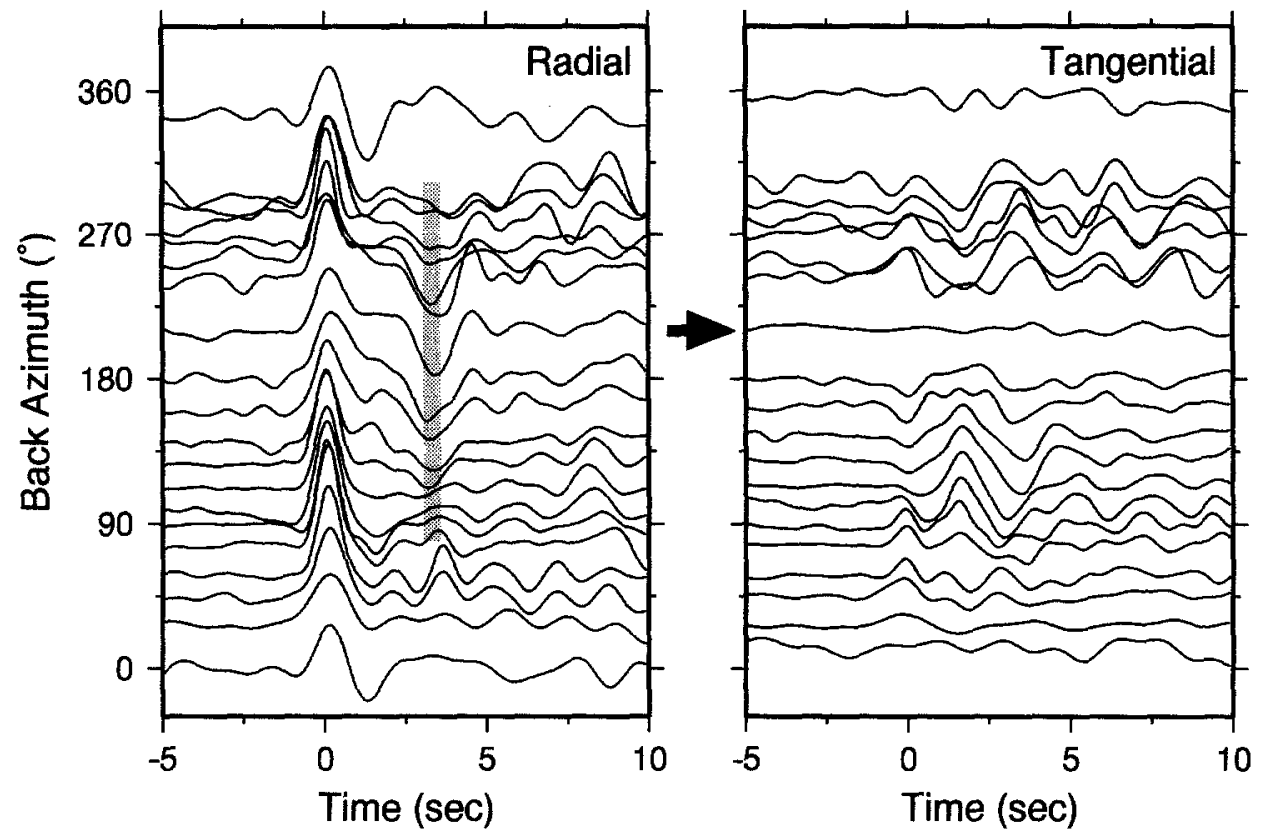

Figure 4. Receiver functions at station BUDO. Horizontal arrow points to the backazimuth with minimum tangential energy. Thick gray line shows a $P$-to- $S$ converted phase on radial components.

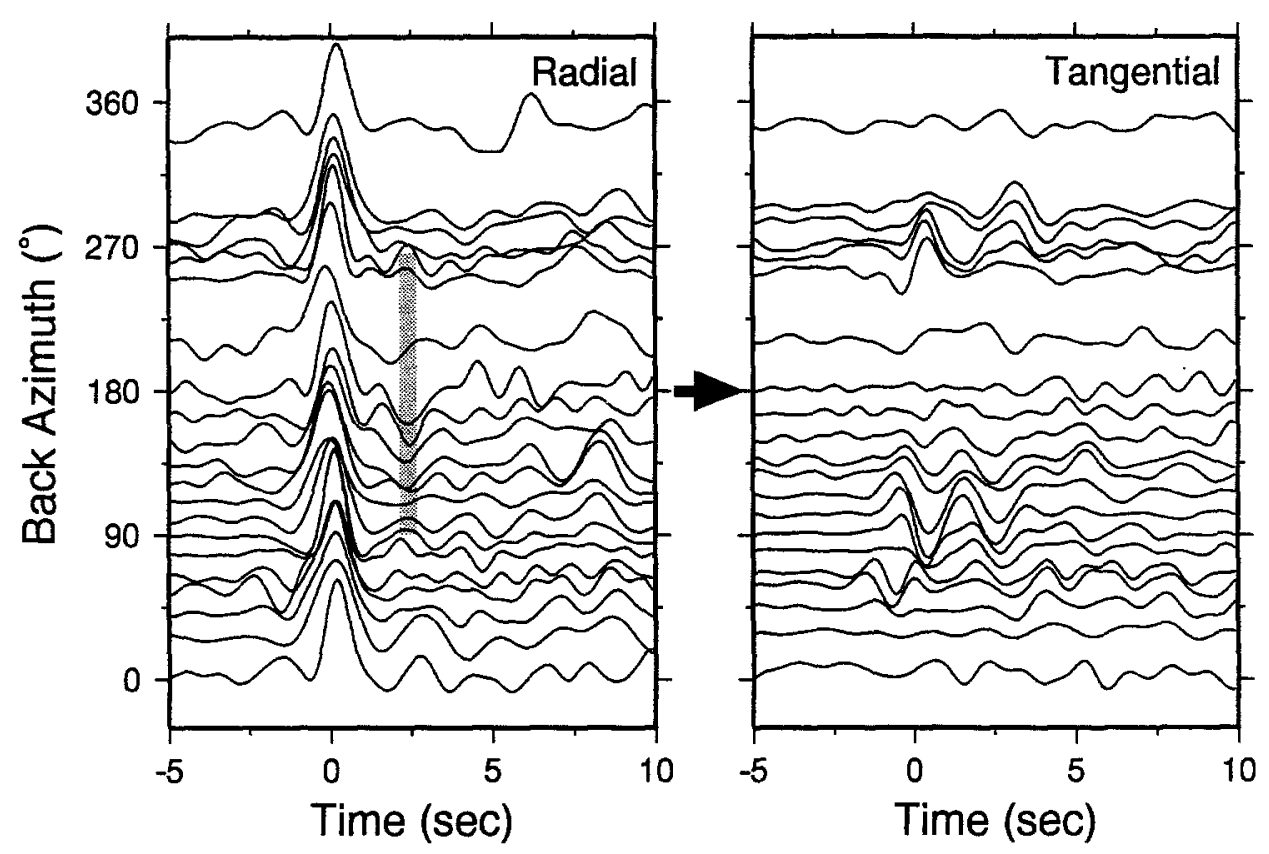

Figure 5. Receiver functions at station TUNL. Horizontal arrow points to the backazimuth with minimum tangential energy. Thick gray line shows a $P$-to- $S$ converted phase on radial components.

of the interface (as demonstrated by the synthetic receiver functions in Fig. 2).

We measured the amplitudes of this phase on both the radial and tangential receiver functions from different backazimuths and fit them by trial-and-error forward modeling. From our preliminary receiver function analysis (Zhu et al.,
1993), we fixed the velocity above the interface at $3.5 \mathrm{~km} /$ $\mathrm{sec}$ and varied the velocity below the interface from 2.8 to $3.3 \mathrm{~km} / \mathrm{sec}$. A range of dip angles from $5^{\circ}$ to $35^{\circ}$ were tested. We used the maximum radial amplitude to estimate the velocity contrast and used the shape of the amplitude variation with backazimuth to estimate the dip angle and direction. 


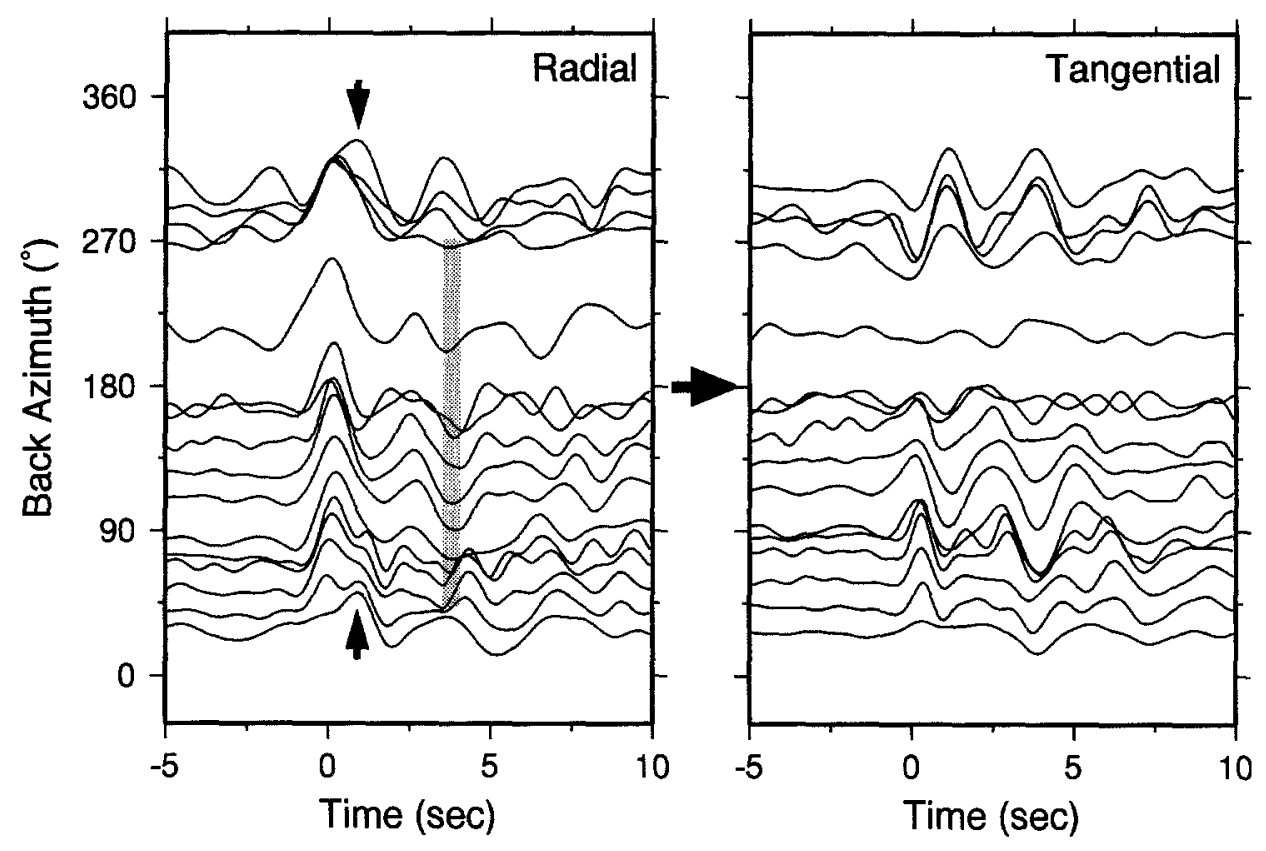

Figure 6. Receiver functions at station ERDO. Horizontal arrow points to the backazimuth with minimum tangential energy. Thick gray line shows a $P$-to- $S$ converted phase on radial components. The apparent time shifts of direct $P$ arrivals are indicated by vertical arrows.

The modeling results are listed on Table 2 . Figure 7 presents the comparisons between data and the values predicted by the dipping models.

There is very good backazimuth sampling at BUDO, which leads to substantial constraint on the velocity below the interface ( 2.8 to $2.9 \mathrm{~km} / \mathrm{sec})$, and the dip angle $\left(20^{\circ}\right.$ to $25^{\circ}$ ). The strike is $\mathrm{N} 110^{\circ}-120^{\circ} \mathrm{E}$. Both the radial and tangential amplitudes variation are well modeled by the dipping structure (Fig. 7). For station TUNL, although the maximum amplitude of the converted phase at this site is less than that at BUDO, the amplitude has a very rapid variation with backazimuth, implying steep dip angle. The velocity below the interface from the modeling is $3.0 \pm 0.1 \mathrm{~km} / \mathrm{sec}$. Dip angle is $30^{\circ} \pm 5^{\circ}$ with strike $\mathrm{N} 90^{\circ} \pm 10^{\circ} \mathrm{E}$. The actual dip angle seems to be even larger. However, with planar dipping interface, a dip angle larger than $35^{\circ}$ for the given velocity contrast will make the transmitted $P$ at the interface turn into head wave. Probably, a curved interface is needed to match the amplitude variation at TUNL. Data at ERDO are relatively scatter, especially on the tangential component. Part of the reason is due to a shallow structure, which we will discuss later. The estimated velocity below the interface is $3.0 \pm$ $0.1 \mathrm{~km} / \mathrm{sec}$, and the dip angle is $20^{\circ} \pm 10^{\circ}$ with strike $\mathrm{N} 60^{\circ}$ $\pm 20^{\circ} \mathrm{E}$. Large uncertainty exists for this station. The depth of the dipping interface at each station is determined by the arrival time of the converted phase, after assuming an average upper-crust $S$ velocity of $3.5 \mathrm{~km} / \mathrm{sec}$ and normal $V_{p} / V_{S}$ ratio. The results are $15 \mathrm{~km}$ for TUNL, $24 \mathrm{~km}$ for BUDO, and $26 \mathrm{~km}$ for ERDO.
Another feature of radial receiver functions is an apparent time shift of direct $P$ arrivals from backazimuths of $30^{\circ}$ and $315^{\circ}$ at ERDO (indicated by the vertical arrows in Fig. 6). This shift is produced by a shallow dipping interface that reduces the direct $P$ arrival amplitude and generates a large $P s$ wave that appears to be the first arrival, as discussed by Owens and Crosson (1988). By adding a top layer beneath ERDO and adjusting the depth, dip, and velocity contrast of the bottom boundary, we can model both the radial and tangential waveform of the first 2 to $3 \mathrm{sec}$ quite well (Fig. 8). The shallow layer has a thickness of $4 \mathrm{~km}$ with bottom interface dipping $15^{\circ}$ to the north (see Table 2).

\section{Low Velocities and High Temperature in the Northern Tibetan Plateau Crust}

Our modeling shows that there is a low-velocity layer (LVL) at depth range of 15 to $25 \mathrm{~km}$ in the crust of the northern Tibetan Plateau. Due to the difficulty of identifying the converted phase from the bottom of the LVL, we cannot determine its thickness. The $S$ velocity reduction of this layer could be as large as 15 to $20 \%$. The LVL is consistent with previous results of surface-wave studies that show that the plateau, especially the north-central part, has a very low average crustal velocity (Romanowicz, 1982; Brandon and Romanowicz, 1986).

Some interesting implication about crustal structure can be derived from the LVL. Earthquake relocations showed that most of the seismicity in the Tibetan Plateau is confined 
Table 2

Velocity Structures from Forward Modeling

\begin{tabular}{|c|c|c|c|c|c|}
\hline Layer & Thickness $(\mathrm{km})$ & $V_{p}(\mathrm{~km} / \mathrm{sec})$ & $V_{s}(\mathrm{~km} / \mathrm{sec})$ & Dip $\left({ }^{\circ}\right)$ & Strike $\left({ }^{\circ}\right)$ \\
\hline \multicolumn{6}{|c|}{ BUDO } \\
\hline 1 & 24 & 6.06 & 3.50 & 25 & 120 \\
\hline 2 & & 4.85 & 2.80 & & \\
\hline \multicolumn{6}{|c|}{ TUNL } \\
\hline 1 & 15 & 6.06 & 3.50 & 30 & 90 \\
\hline 2 & & 5.20 & 3.00 & & \\
\hline \multicolumn{6}{|c|}{ ERDO } \\
\hline 1 & 4 & 4.33 & 2.50 & 15 & 270 \\
\hline 2 & 22 & 6.06 & 3.50 & 20 & 60 \\
\hline 3 & & 5.20 & 3.00 & & \\
\hline
\end{tabular}

to the top 5 to $10 \mathrm{~km}$ of the crust (Molnar and Chen, 1983; Zhao and Helmberger, 1991; Randall et al., 1995). It was estimated that earthquake cutoff temperature for continental crust is about $250^{\circ} \mathrm{C}$ to $450^{\circ} \mathrm{C}$ (Chen and Molnar, 1983). Thus, shallow seismicity indicates high geotherm gradient. Kern and Richter (1981) calculated temperature derivatives of $V_{p}$ and $V_{S}$ from laboratory measurements and showed that in a warm geotherm situation, velocity inversion can occur for rocks rich in olivine or quartz. However, velocity decrease by a high-temperature gradient is limited (less than $13 \%$, Meissner, 1986). For larger velocity reduction, almost necessarily, partial melt is involved. Dehydration reaction could be another reason but is less likely in our case.

Partial melting is consistent with the observation of high-frequency $S$-wave attenuation in north-central Tibet (Barazangi and Ni, 1982; $\mathrm{Ni}$ and Barazangi, 1983; McNamara et al., 1995a; Zhu and Helmberger, 1995). It is also supported by abundant evidence for late-Cenozoic volcanism in the area. Molnar et al. (1987) reported discovery of a suite of igneous rocks that includes tourmaline-bearing granite, two-mica granite, and sanidine-bearing welded tuff near the Ulugh Muztagh area, northern Tibet. These very acidic rocks were believed to result from the melting of crustal rocks (Molnar et al., 1987). Basaltic volcanic rocks were also reported (Deng, 1978), which suggests that an upper-mantle component is also involved (Molnar, 1988).

High-crustal temperature could arise from the concentration of radiogenic crustal material as a result of crustal shortening during the formation of the plateau (Zhao and Helmberger, 1991), or due to the high heat flux from abnormal upper-mantle under the north-central plateau (Molnar, 1988). There is ample evidence for a hot upper-mantle beneath this area, for example, the high-Sn attenuation and the low-Pn velocities from recent tomography studies (Zhao and Xie, 1993; McNamara et al., 1995b).

\section{Dipping.Velocity Interfaces and Thrust Faults}

The strikes of dipping interfaces we obtained are consistent with the E-W trend of surface geology. These inter- faces may be associated with thrust faults observed in the brittle upper crust of the area. For example, the shallow northward-dipping interface under ERDO could be related to the Fenghuoshan thrust faults that run E-W in the south of the station (Kidd et al., 1988). It is estimated that a significant amount of crust shortening occurred in the Tibetan Plateau as the Indian plate collided and indented into the Eurasia. Palaeomagnetic data provided a rough relative movement between the two plates and showed that about $2000 \mathrm{~km}$ of crustal shortening has occurred between the Indo-Zanbo collision suture and the Siberia (Patriat and Achache, 1984; Lin and Watts, 1988). Accommodating such a large amount of crustal shortening requires folding and thrust faulting within the plateau or along the north and south boundaries. Large-scale thrust faults exist along the Himalayan front and the northwest boundary between the Tibetan Plateau and Tarim Basin. Recent geological expeditions also found evidences of thrust faults in northern Tibet (Molnar et al., 1987; Tapponnier et al., 1990).

\section{Conclusions}

In summary, the waveform variation of receiver functions with backazimuth at three stations located in the northern Tibetan Plateau shows that there are strong lateral heterogeneities within the upper-middle crust in this region. The waveform variation pattern also indicates that they are mainly produced by $\mathrm{E}-\mathrm{W}$-striking dipping interfaces. The strike direction is consistent with the E-W trend of surface geology. Modeling a negative-polarity $P$-to- $S$ converted phase in the receiver functions at each station shows that there is a mid-crustal low-velocity layer with upper boundary dipping $20^{\circ}$ to $30^{\circ}$ to the south. The low-velocity layer, together with other geological and seismological observations, suggests that there is a hot, possibly partial melt zone in the middle crust of northern Tibet. Alternately, dipping velocity interfaces might be associated with some buried thrust faults in the upper crust that accommodated crust shortening during the plateau formation.

Shallow and mid-crustal dipping interfaces have noticeable impact on the modeling of deep structure such as the Moho. As demonstrated in our synthetic receiver functions in Figure 2, the multiple converted phases of the dipping interface interferes with the Moho $P s$, and the amplitude of Moho $P S$ varies with backazimuth. For a crustal thickness of about $65 \mathrm{~km}$, the predicted arrival time of Moho $P S$ is 7.5 to $8 \mathrm{sec}$ after the direct $P$ arrival. However, at all three stations, we have not consistently observed Moho $P S$ on the receiver functions profiles (Figs. 4 through 6). As the receiver function method is being widely used for both permanent and portable stations, more attention should be given to these heterogeneity effects on the waveform modeling. 

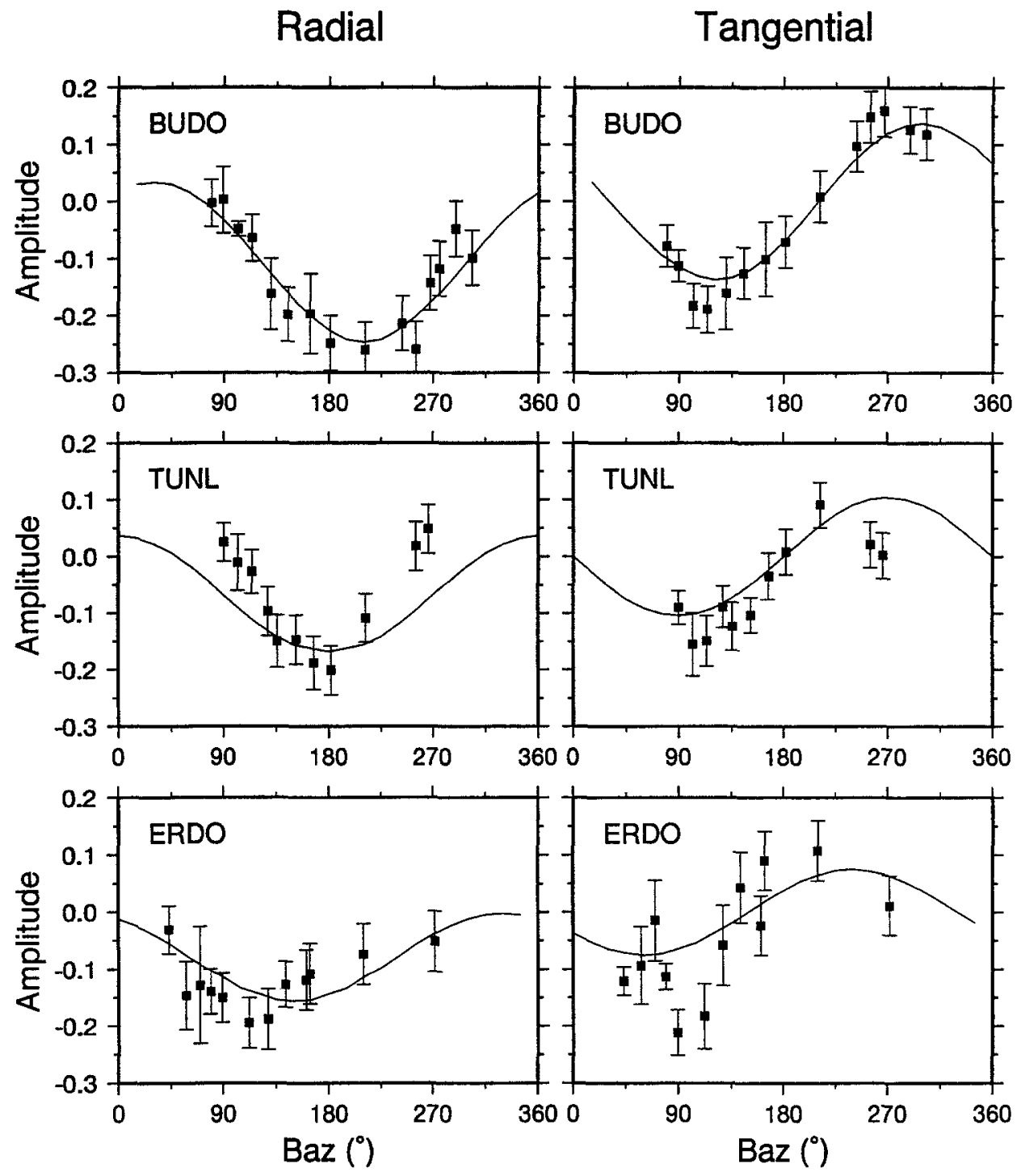

Figure 7. The amplitudes of the mid-crustal converted phases and theoretical modelings (solid lines). The modeling results are listed on Table 2.

\section{Acknowledgments}

We thank C. J. Ammon for his careful review of the manuscript. This work was supported at University of South Carolina under NSF Grants EAR-9196115. It has also been supported at Caltech by the Department of Defense as monitored by the Air Force Office of Scientific Research under Contract F49620-92-J-0470. Contribution No. 5540, Division of Geological and Planetary Sciences, California Institute of Technology, Pasadena, California.

\section{References}

Ammon, C. J., G. E. Randall, and G. Zandt (1990). On the nonuniqueness of receiver function inversions, J. Geophys. Res. 95, 15303-15318.

Argand, E. (1924). La tectonique de l'Asie, Proc. 13th Int. Geol. Congr. Brussels 1924, 7, 171-372.

Barazangi, M. and J. Ni (1982). Velocities and propagation characteristics of $\mathrm{Pn}$ and $\mathrm{Sn}$ beneath the Himalayan arc and Tibetan plateau: Possible evidence for underthrusting of Indian continental lithosphere beneath Tibet. Geology 10, 179-185.
Beghoul, N., M. Barazangi, and B. Isacks (1993). Lithospheric structure of Tibet and western North America, mechanisms of uplift and a comparative study, J. Geophys. Res. 98, 1997-2016.

Brandon C. and B. Romanowicz (1986). A no-lid zone in the central ChangThang platform of Tibet, evidence from pure path phase-velocity measurements of long period Rayleigh-waves, J. Geophys. Res. 91, $6547-6564$.

Chen, W. and P. Molnar (1983). Focal depths of intracontinental and intraplate earthquake and their implications for the thermal and mechanical properties of the lithosphere, J. Geophys. Res. 88, 41834214.

Deng, W. A. (1978). A preliminary study on the petrology and petrochemistry of Quaternary volcanic rocks of northern Tibet autonomous region, Acta Geol. Sinica 52, 148-162.

Dewey, J. F. and J. M. Bird (1970). Mountain belts and the new global tectonics, J. Geophys. Res. 75, 2625-2647.

Dewey, J. F. and K. Burke (1973). Tibetan, Variscan and Precambrian basement reactivation: products of a continental collision, J. Geol. 81, 683-692.

Dewey, J. F., R. M. Shackleton, C. Chang, and Y. Sun (1988). The tectonic 

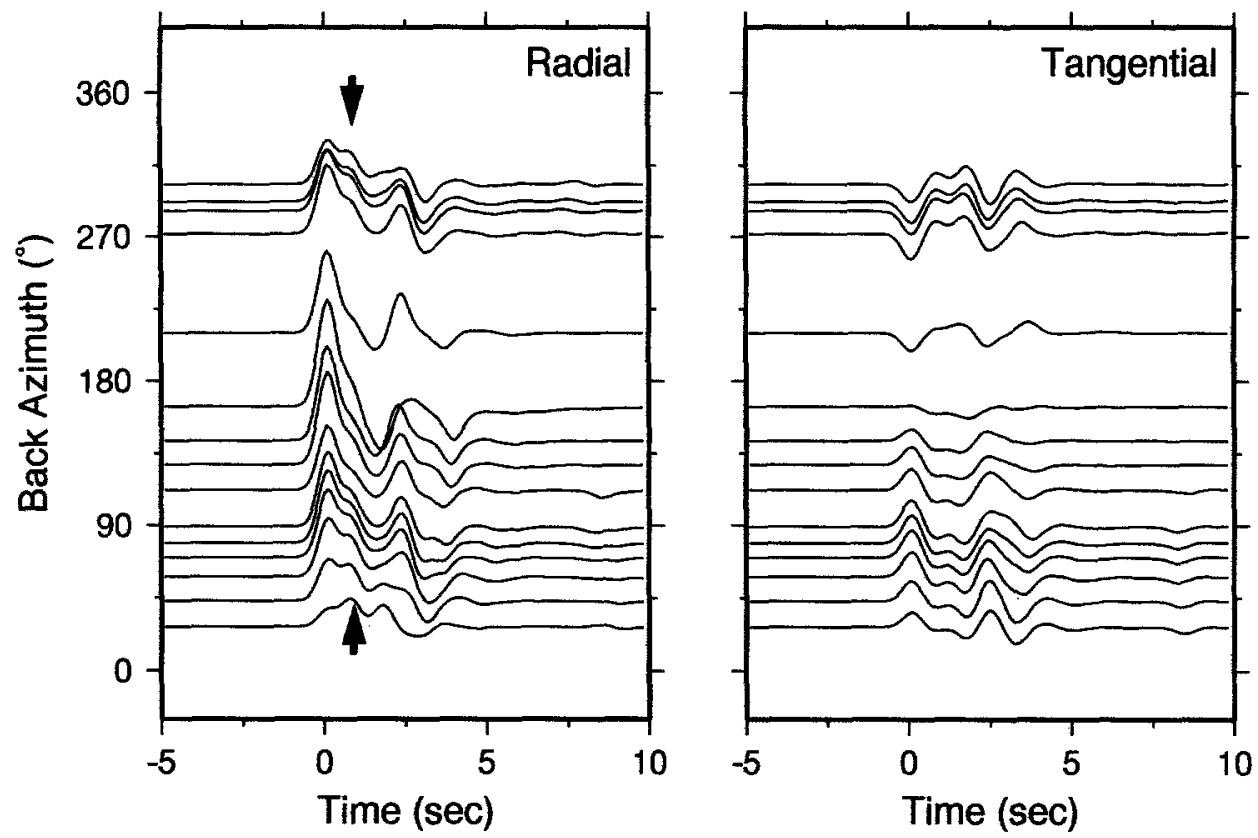

Figure 8. Synthetic receiver functions for station ERDO. Velocity model is listed on Table 2.

evolution of the Tibetan Plateau, Phil. Trans. Roy. Soc. London A 327, 379-413.

Kern, H. and A. Richter (1981). Temperature derivatives of compressional and shear wave velocities in crustal and mantle rocks at $6 \mathrm{kbar}$ confining pressure, J. Geophys. 49, 47-56.

Kidd W. S. F., Y. Pan, C. Chang, M. P. Coward, J. F. Dewey, A. Gansser, P. Molnar, R. M. Shackleton, and Y. Sun (1988). Geological mapping of the 1985 Chinese-British Tibetan (Xizang-Qinghai) Plateau Geotraverse rout, Phil. Trans. Roy. Soc. London A 327, 287-305.

Langston, C. A. (1977). The effect of planar dipping structure on source and receiver responses for constant ray parameter, Bull. Seism. Soc. Am. 67, 1029-1050.

Langston, C. A. (1979). Structure under Mount Rainier, Washington, inferred from teleseismic Body waves, J. Geophys. Res. 84, 4749-4762.

Lin, J. and D. Watts (1988). Palaeomagnetic results from the Tibetan plateau, Phil. Trans. Roy. Soc. London 327, 239-262.

McNamara, D. E., T. J. Owens, and W. R. Walter (1995a). Observations of regional phase propagation in the Tibetan Plateau, J. Geophys. Res., submitted.

McNamara, D. E., T. J. Owens, and W. R. Walter (1995b). Upper mantle velocity structure beneath the Tibetan Plateau from $\mathrm{Pn}$ travel time tomography, submitted to Nature.

Meissner, R. (1986). The Continental Crust, a Geophysical Approach, Academic Press, Orlando, 361-362.

Molnar, P. (1988). A review of geophysical constraints on the deep structure of the Tibetan Plateau, The Himalaya and the Karakoram, and their tectonic implications, Phil. Trans. Roy. Soc. London A 326, 33 88.

Molnar, P. and P. Tapponnier (1977). Relation of eastern China to the IndiaEurasia collision: application of slip-line field theory to large-scale continental tectonics, Geology 5, 212-216.

Molnar, P. and W. Chen (1983), Focal depths and fault plane solution of earthquakes under the Tibetan Plateau, J. Geophys. Res. 88, 11801196.

Molnar, P., B. C. Burchfiel, Z. Zhao, K. Liang, S. Wang, and M. Huang (1987). Geologic evolution of Northern Tibet: results of an expedition to Ulugh Muztagh, Science 235, 249-253.

$\mathrm{Ni}$ J. and M. Barazangi (1983). High-frequency seismic-wave propagation beneath the Indian shield, Himalayan arc, Tibetan Plateau and surrounding regions-high uppermost mantle velocities and efficient $\mathrm{Sn}$ propagation beneath Tibet. J. Geophys. Res. 72, 665-689.

Owens, T. J., G. E. Randall, F. T. Wu, and R. S. Zeng (1993). PASSCAL instrument performance during the Tibetan plateau passive seismic experiment, Bull. Seism. Soc. Am. 83, 1959-1970.

Owens, T. J., G. Zandt, and S. R. Taylor (1984). Seismic evidence for ancient rift beneath the Cumberland plateau, Tennessee: A detailed analysis of broadband teleseismic P waveforms, J. Geophys. Res. 89, 7783-7795.

Owens, T. J. and R. S. Crosson (1988). Shallow structure effects on broadband teleseismic P waveforms, Bull. Seism. Soc. Am. 77, 96-108.

Patriat, P. and J. Achache (1984). India Eurasia collision chronology has implications for crustal shortening and driving mechanism of plates, Nature 311, 615-621.

Randall, G. E., C. J. Ammon, and T. J. Owens (1995). Moment-tensor estimation using regional seismograms from a Tibetan plateau portable network deployment, Geophys. Res. Lett., 22, 1665-1668.

Romanowicz, B. (1982). Constraints on the structure of the Tibet Plateau from pure path phase velocities of love and Rayleigh-waves, $J$. Geophys. Res. 87, 6865-6883.

Tapponnier, P., B. Meyer, J. P. Avouac, G. Peltzer, and Y. Gaudemer (1990). Active thrusting and folding in the Qilian-Shan, and decoupling between upper crust and mantle in northeastern Tibet, Earth Planet. Sci. Lett. 97, 382-403.

Tapponnier, P., G. Peltzer, A. Y. Ledain, R. Armijo, and P. Cobbold (1982). Propagating extrusion tectonics in Asia: new insight from simple experiments with plasticine, Geology 10, 611-616.

Zhao, L. and D. V. Helmberger (1991). Geophysical implication from relocation of Tibetan earthquakes-hot lithosphere, Geophys. Res. Lett. $18,2205-2208$.

Zhao, L. and J. Xie (1993). Lateral variation in compressional velocities beneath the Tibetan Plateau from Pn travel-time tomography, Geophys. J. I 115, 1070-1084.

Zhao, W. and J. Morgan (1985). Uplift of the Tibet Plateau, Tectonics 4, 359-369.

Zhu, L., R. Zeng, F. Wu, T. J. Owens, and G. E. Randall (1993). Preliminary study of crust-upper mantle structure of the Tibet Plateau by using 
broadband teleseismic body waveforms, Acta Seism. Sinica 6, 305316.

Zhu, L. and D. V. Helmberger (1995). High frequency S-wave attenuation on the Tibet Plateau (abstract), Seism. Res. Lett. 66, 53.

Seismological Laboratory

California Institute of Technology

Pasadena, California 91125

(L.Z.)
Department of Geological Sciences

University of South Carolina

Columbia, South Carolina 29208

(T.J.O., G.E.R.) 